\title{
The effect of volleyball training program on students' depression levels in private primary and secondary schools
}

\author{
İbrahim BOZKURT ${ }^{1}$, Mehibe AKANDERE ${ }^{1}$, Gaye ERKMEN¹, Elif Aycan \\ ATAK $^{2}$
}

${ }^{1}$ Selcuk University, Sport Sciences Faculty, Konya, Turkey

${ }^{2}$ Selcuk University Health Sciences Institute, Konya, Turkey

Address Correspondence to İ. Bozkurt, e-mail: ibozkurt@selcuk.edu.tr

\begin{abstract}
The purpose of the study was to investigate the the effect of volleyball training program, as a leisure activity, on students depression levels. The sample of the study consists of 202 students (intervention group), 201 students (control group). Eight weeks training program was prepared and conducted at the intervention group. This study was a pretest posttest experimental research design with control group. The data of the research were collected with demographic information form and Depression Scale for Children. To revealed that whether there were differences between pretest and posttest depression scores of intervention and control groups ANCOVA analysis was conducted. Results revealed that there was a significant difference between students pretest and posttest depression scores of intervention and control groups $(p=.000)$. According to ANCOVA findings, students of intervention and control groups' pretest depression scores were controlled, there were significant differences between intervention and control group students' posttest depression scores $\left(F_{(2-400)}=821.24, p=.000\right)$. It was revealed that volleyball training program have an impact on having a lower depression scores of the students in the intervention group than depression scores of the students in the control group. In this respect, in order to ensure that children are away from depression and to be healthier individuals in their physical and spiritual life, their educational processes should be supported by participating sport, physical activities and games. It is considered that students should be directed to various sporting activities by family, school administration and physical education teachers.
\end{abstract}

Key words: Volleyball, depression, leisure, students.

\section{INTRODUCTION}

A bidirectional relationship between depression and inactivity has been suggested recently, since inactivity causes depression and depression causes inactivity (10). Depression is defined as a mood disorder that affects a person's behaviors, feelings, thoughts, self-perception, interpersonal relationships, biological process, physiologic functioning, productivity and satisfaction with life (1).

The available epidemiological data indicates that depression, as the most diagnosed mental health disorder $(20 \%)$ in children and adolescents, has a global prevalence. Depression causes social (12) and cognitive developmental disorders that are reflected in the family and social environment, a decrease in school performance (19), aggression, tension or short temper in children and young people.
The possibility that physical activity can prevent from depression or develop some symptoms of depression has become the focus of the relevant studies. Exercise interventions are gaining increasing attention in especially coping with depression $(20,24,22)$. When the systematic reviews (4) conducted on studies that put the effect of exercise on depression forward are investigated, it is seen that the physical activity applications have a promising influence on children and adolescents.

In a study conducted by Motl et al. (2004), the inverse proportion between the change in the physical activity and depressive symptoms during the prepubescent period was reported. A literature review (27) supported the idea that physical activity decreases symptoms of depression if it is enthusiastic and in the form of leisure activity. Physical activity had a positive impact on children and adolescents in terms of the self-respect and 
some problems like depression and anxietybehavioral disorder (9). The requirement of improving life-style and exercise through physical activity is regarded as an instrumentality for increasing the positive well-being of children (28). A negative relationship was proven between physical activity and depression in adolescents (11, 25). Moreover, the relationship between regular sport and depression-anxiety was investigated and regular sport was found beneficial for reducing depression and anxiety $(5,26)$.

Depression related situations are encountered in primary and secondary education ages because of various factors. Sport activities are very important due to its therapeutic effects for children to live a bodily, mentally and spiritually healthy life. In the present study, while taking into consideration the role of sport activities in reducing depression, whether the sport of volleyball as a leisure activity has any influence on depression levels of primary and secondary school students was investigated.

\section{METHOD}

This research was carried out by applying a Participants: The sample of this study was comprised of 101 females (Mage $=11.38, \mathrm{SD}=1.70$ ) and 101 males (Mage $=11.14, \mathrm{SD}=1.33$ ) as the intervention group and 100 females (Mage $=11.10$, $\mathrm{SD}=1.41)$ and 101 males (Mage $=11.94, \mathrm{SD}=1.18)$ as the control group, making a total of 403 students; and all of whom were primary and secondary school students aged 7-15 years, and were in a private school in Konya province. Convenient sampling method was used for the collecting study sample.

Measures: Demographic information form developed by researchers and Depression Scale for Children were used as the data collection instruments in the present research.

Depression Scale for Children: It is a self-rated psychological assessment tool developed by Kovacs (1981) to detect depression levels of 7-17 aged children, which was prepared through using Beck Depression Inventory as a model. The scale consists of 27 items, every item includes three options and the items are identified with a rating of 0,1 or 2 according to the severity of the response as a depression symptom. A highness of the total score is interpreted as a high depression level. The scale was adapted in to Turkish by Öy (1990). The scale's correlation coefficient detected through the testretest reliability in Turkey was calculated as .80. The coefficient of internal consistency for present study was found .78.

Data collection: Since a pretest-posttest control group design was applied in this study, data were collected from the intervention group and control group at the beginning of the study and eight weeks after. The intervention group was exercised by volleyball as a leisure activity for a period of eight weeks. The control group was not exercised during the eight weeks. The participants were informed about the study and volunteered to participate before the form included the scale was given. The forms included the scales were filled up within approximately 10 minutes.

Content of the intervention program: The duration of the intervention part of the study was planned as 8 weeks and the volleyball exercises as a leisure activity was done twice a week. Some educational games took place often at the break times within the scope of the applied plan. The aim here was to provide children with some quality time and fun while they were exercising. Table 1 shows the 8 weeks intervention program for the control and intervention groups.

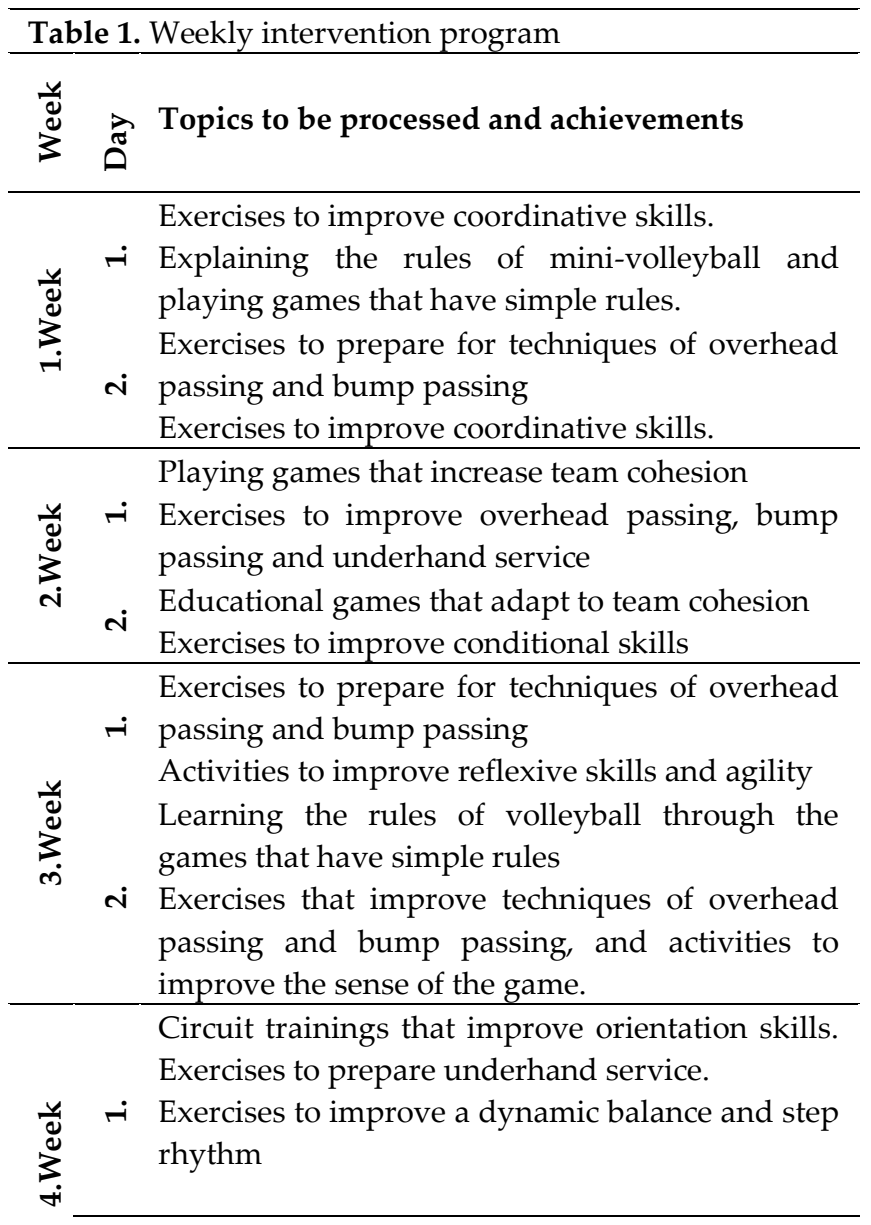

$\sim$ Exercises that improve techniques of overhead 
passing and bump passing.

Exercises to improve main techniques of volleyball

Circuit trainings that improves condition.

- Learning the rules of mini volleyball game. Activities to enhance the intelligence for team cohesion

Exercises that improve techniques of overhead passing and bump passing

$i^{2}$ Exercises that improve techniques of overhead passing and bump passing. Exercise to improve steps leading to a spike and to develop the spike arm

Exercises to improve the rhythmic, kinesthetic

$\sim \sim$ and reflexive skills

Exercises to improve speed.

$\sum_{0}^{\frac{y}{0}}$

Games that have simple rules to improve overhead passing and bump passing.

$i$ Exercises to improve a dynamic balance. Exercises to improve main techniques of volleyball.

Exercises to improve balance skills and to gain a

$\sim$ i static balance.

Activities and games that improves attention.

Exercises to improve the space perception and

i sense of the ball.

Improving the mentality of volleyball through games that have simple rules.

Technical exercises and games to improve

. attention skill.

Exercises that improve overhead passing, bump passing and underhand service.

Games that have simple rules to improve the

$i$ techniques of overhead passing and bump passing.

Circuit trainings to improve condition.

Data analysis: In the present study, normality of the data and homogeneity of the variances were tested initially, following with analyzing the descriptive statistics, and later on one-way analyses of covariance (ANCOVA) was performed on the purpose of the study to detect whether there was a difference in pretest-posttest depression scores between the intervention group and control group. The pretest depression scores of the intervention group and control group were taken under control and compared with the scores obtained from the posttest. The level of significance for this study was determined as .05 and SPSS 22.0 (IBM SPSS) packet program was used for statistical analyses.

\section{RESULTS}

To be able to identify the extreme values that are the premises of covariance analyses $\mathrm{z}$ scores were studied and 26 extreme values in total were excluded from the data set $(z>0.186)$. The sample consisted of 403 participants after the exclusion of data. The significance coefficient of Levene's test was analyzed to see the equality of variances between groups, and a significant difference between the mean values of the two groups was detected. The assumption of multivariable linearity in terms of dependent variables was investigated through the scatter plot, and as a result, the linearity assumption was verified.

Table 2 shows the mean values and standard deviations of pretest-posttest scores of the intervention group and control group. The intervention group's mean value of the pretest depression score was found $(M=11.06)$ and of the posttest depression score was found $(M=7.43)$; the control group's mean value of the pretest depression score was found $(\mathrm{M}=8.63)$ and of the posttest depression score was found $(M=15.20)$. Moreover, an independent $t$ test was conducted to determine whether there was a significant difference in pretestposttest depression scores between the intervention and control group. Table 2 shows the findings obtained. According to obtained findings, there were significant differences in pretest $(p=.000)$ and posttest $(p=0.000)$ depression scores between intervention and control groups. The independent $t$ tests conducted to determine whether there was a significant difference between intervention and control groups at the beginning of the study showed that the two groups were not equal to each other.

Table 2. Independent t-test results related to comparison between pretest-posttest results of the intervention and control groups

\begin{tabular}{llcccc}
\hline Group & & $\mathbf{M}$ & $\mathbf{S D}$ & $\mathbf{t}$ & $\mathbf{p}$ \\
\hline \multirow{3}{*}{ Intervention } & $\begin{array}{l}\text { Pretest } \\
(\mathrm{n}=202)\end{array}$ & 11.06 & 1.82 & & \\
\cline { 2 - 4 } & $\begin{array}{l}\text { Posttest } \\
(\mathrm{n}=202)\end{array}$ & 7.43 & 1.11 & 0.32 & 0.000 \\
\cline { 1 - 4 } Control & $\begin{array}{l}\text { Pretest } \\
(\mathrm{n}=201)\end{array}$ & 8.63 & 1.35 & & \\
\cline { 2 - 4 } & $\begin{array}{l}\text { Posttest } \\
(\mathrm{n}=201)\end{array}$ & 15.20 & 3.04 & & 0.000 \\
\hline
\end{tabular}

After analyses it was proved that the volleyball exercise program applied in the intervention group as a leisure activity decreased the depression scores of the students. Besides, there was an increase in the posttest depression scores of the control group.

ANCOVA analyses was performed through taking the pretest scores as the covariate to detect if 
there was any significant difference in posttest scores between control and intervention groups and to determine if the possible significant difference was resulted from the intervention program. Table 3 shows the results of the ANCOVA analyses.

Table 3. Common Impact Result for the Posttest Scores of the Intervention and Control Groups (ANCOVA)

\begin{tabular}{lcccccc}
\hline $\begin{array}{l}\text { Source of } \\
\text { variance }\end{array}$ & $\begin{array}{c}\text { Sum of } \\
\text { squares }\end{array}$ & df & $\begin{array}{c}\text { Mean } \\
\text { square }\end{array}$ & F & p & $\begin{array}{c}\text { Eta } \\
\mathbf{2}\end{array}$ \\
\hline Pretest & 424.15 & 1 & 424.157 & 82.721 & .000 & .171 \\
\hline Group & 8421.94 & 2 & 4210.97 & 821.241 & .000 & .804 \\
\hline Error & 2051.03 & 400 & 5.128 & & & \\
\hline Total & 65497.00 & 403 & & & & \\
\hline
\end{tabular}

According to results of ANCOVA analyses where the pretest results of the students were taken as the covariate, a statistically significant difference was found between the posttest depression scores of the students $(\mathrm{F}(2-400)=821.24, \mathrm{p}=.000)$ when the pretest depression scores of the intervention group which was applied with a volleyball exercise program planned as a leisure activity and of the control group which was applied with non of intervention were taken under control. In other words, the decrease in the depression scores of the students was related to volleyball exercise programmed as a leisure-time activity. The volleyball exercise program given for the intervention group had a remarkable impact on the decline of the students' depression scores.

\section{DISCUSSION}

As a result of the study conducted to investigate whether if the volleyball exercise program as a leisure activity has any influence on the depression levels of primary and secondary school students, the eight week intervention program was found efficient in decreasing the depression levels of the students.

It was asserted that the adolescents who regularly participate a physical activity have lower depression and anxiety levels and exhibits less social and behavioral problems compared to their age mates who are less active (15). Larun and colleagues (2006) found significant differentiation in a study of the depression scores was found in the comparison of the individuals applied with exercise and individuals who were not. The time during a physical activity was found inversely proportional to the depression levels of adolescents $(11,13)$. In a longitudinal study (6), it was reported that individuals who do not do sports do not have the risk of developing depression, but have shown a decrease in the symptoms of depression when Turk ل Sport Exe 2018; 20(3): 152 - 157 ๑ 2018 Faculty of Spart Sciences, Selcuk University compared to the data collected 9 years after. In another study (8), it is stated that the children who attended aerobically dense physical activity programs had lower depression levels. In a study conducted by Akandere (2003), a significant difference in depression levels was found between university students who were doing sport and who were not, the depression levels of the students who were doing sport were lower than the other group.

Weinstein and Meyers conducted a study (1983) included 45 minutes aerobic runs and exercises two days a week with the male college students whose ages ranged from 18 to 23 , and a remarkable decrease in students' depression scores was seen as a result of the study when compared to beginning of the study. Some performed studies $(3,16)$ concluded that sport and regular exercises play an active role in decreasing the depression and anxiety levels of individuals, and can have some remedial specialties to cure such mood disorders. İlhan and Gencer (2009) detected a significant decline in neurotic problems of the intervention group after the application of 12 weeks regular badminton exercise educational program in their study. In a study conducted by Canan and Ataoğlu (2010), an inversely linear relationship was detected between the time duration in which a sport and the findings of depression and anxiety, and a direct relationship was detected between the time duration in which a sport activity and the sense of problem solving ability. The findings collected from the studies in literature are parallel with the findings of our study. The conducted studies support the ideas that sports and physical activities have influence on depression levels and mental health, and can be used as a treatment method to develop depressive symptoms.

There were some limitations in the present study which suggested that the volleyball exercise program decreases the depression levels. The constitution of the students sample from only one college limits the generalization of the findings. Additionally, inclusion of both primary and secondary school students causes a heterogeneous structure in terms of the age groups. As another limitation, the obscurity of the cause of the increase in the control group's posttest depression scores with respect to the pretest scores complicates the interpretation of the results. For this study, it is thought that the occurence of the data collection at the same time with the exam period had a role in the increase of students' depression levels. 


\section{CONCLUSION \& SUGGESTIONS}

According to present study, the exercise program given as a leisure activity had a positive impact on the spiritual health of the students. It is thought that students should be supported with some physical activities, participations in sports and game activities to reduce the possible pressure of increased exam anxiety in this day and age on them, and to improve the chances for them to be happy individuals. Due to this fact, directing students to sport activities by their physical education teacher, school management and school counselor after evaluating them with respect to their interests and abilities is considered as a crucial practice.

\section{REFERENCES}

1. Abela JRZ, Hankin BL. Cognitive vulnerability to depression in children and adolescence: A developmental psychopathology approach. In: Handbook of Child and Adolescent Depression, Abela J.R.Z, Hankin B.L (ed). Guilford, New York, 2007, s. 35-78.

2. Akandere M, Serdengeçti C. Spor Yapan ve Yapmayan Öğrencilerin Depresyon Düzeylerinin İncelenmesi, Spor ve Tip Dergisi, Sendrom, 2003, 4, (2), 1.

3. Arslan C, Güllü M, Tutal V. Spor Yapan ve Yapmayan İlköğretim Öğrencilerinin Depresyon Durumlarının Bazı Değişkenlere Göre İncelenmesi. Niğde Üniversitesi Beden Eğitimi Ve Spor Bilimleri Dergisi, 2011, Cilt 5, Say1 2.

4. Biddle SJH, Asare M. Physical activity and mental health in children and adolescents: a review of reviews, British Journal of Sports Medicine, 2011, 45, 886-895.

5. Byrne A, Byrne DG. The effect of exercise on depression, anxiety and other mood states-A review. J Psychosom Res, 1993, 37, 565-574.

6. Camacho TC, Roberts RE, Lazarus NB. Physical activity and depression: Evidence from the Alameda County study, American Journal of Epidemiology, 1991, 134, 220-231.

7. Canan F, Ataoğlu A. Anksiyete, depresyon ve problem çözme becerisi algisı üzerine düzenli sporun etkisi, Anatolian Journal of Psychiatry, 2010, 11, 38-43.

8. Crews DJ, Lochbaum MR, Landers DM. Aerobic physical activity effects on psychological well-being in low-income Hispanic children. Percept Mot Skills, 2004, 98, 319-24.

9. Ekeland E, Heian F, Hagen KB. Can exercise improve selfesteem in children and young people? A systematic review of randomized controlled trials. Br J Sports Med, 2005, 39, 792798.

10. Elfrey MK, Ziegelstein RC. The "inactivity trap". Gen Hosp Psychiatry, 2009, 31(4), 303-5.

11. Goodwin RD. Association between coping with anger and feelings of depression among youths. Am J Public Health, 2006, 96, 664-9.

12. Guberman C, Manassis K. Symptomatology and family functioning in children and adolescents with comorbid anxiety and depression. J Can Acad, Child Adolesc Psychiatry, 2011, 20 (3), 186-195.

13. Hong X, Li J, Xu F, Tse LA, Liang Y, Wang Z et al. Physical activity inversely associated with the presence of depression among urban adolescents in regional China. BMC Public Health, 2009, 9: 148

14. İlhan L, Gencer E. Çocuklarda Nevrotik Sorun Düzeyleri ve Badminton Eğitimi İlişkisine Yönelik Bir Araştırma, Kocaeli Üniversitesi 4. Raket Sporları Sempozyumu, Bildiriler Kitabı, 11-12 Aralık 2009, Kocaeli.

15. Kirkcaldy BD, Shephard RJ, Siefen RG. The relationship between physical activity and self-image and problem behaviour among adolescents. Soc Psychiatry Psychiatr Epidemiol, 2002, 37: 544-50.

16. Koruç Z, Bayar P. Egzersizin Depresyon Tedavisindeki Yeri ve Etkileri. Spor Bilimleri Dergisi, 2004, 15 (1),s. 50-61.

17. Kovacs M. The Children's depression inventory. Psychopharmalogical Bulletin, 1981, 1, 995-998.

18. Larun L, Nordheim LV, Ekeland E, Hagen KB, Heian F. Exercise in prevention and treatment of anxiety and depression among children and young people. Cochrane Database of Sys Rev, 2006, Issue 3, Art. No: CD004691.

19. Lundy SM, Silva GE, Kaemingk KL, Goodwin JL, Quan SF. Cognitive functioning and academic performance in elementary school children with anxious / depressed and with drawn symptoms. Open Pediat Med J., 2010, 4, 1-9.

20. Martinsen EW. Physical activity in the prevention and treatment of anxiety and depression. Nord J Psychiatry, 2008, 62 Suppl, 47: 25-9.

21. Motl RW, Birnbaum AS, Kubik MY, Dishman RK. Naturally occurring changes in physical activity are inversely related to depressive symptoms during early adolescence. Psychosom Med, 2004, 66, 336-342.

22. Norris R, Carroll D, Cochrane R. The effects of physical activity and exercise training on psychological stress and well-being in an adolescent population. J Psychosom Res., 1992, 36(1):55-65.

23. Öy B. Çocuklar için depresyon ölçeği, Bilişsel Terapilerde Değerlendirme: Sık Kullanılan Ölçekler (Assessment in Cognitive Therapies: Commonly Used Scales), İ. Savaşır and N.H. Şahin, Ankara: Türk Psikologlar Derneği Yayınları (Turkish Association of Psychologists Publications), 1997, 136-143.

24. Petty KH, Davis CL, Tkacz J, Young-Hyman, D, Waller JL. Exercise effects on depressive symptoms and self-worth in overweight children: a randomized controlled trial. J Pediatr Psychol., 2009, 34 (9), 929-39.

25. Sallis JF, Prochaska JJ, Taylor WC. A review of correlates of physical activity of children and adolescents. Med Sci Sports Exerc, 2000, 32, 963-75.

26. Salmon P. Effects of physical exercise on anxiety, depression, and sensitivity to stress: A unifying theory. Clin Psychol Rev, 2000, 21, 33-61.

27. Teychenne M, Ball K, Salmon J. Physical activity and likelihood of depression in adults: a review. Prev Med, 2008, 46 (5), 397-411. 
28. Thogersen-Ntoumani C, Fox KR, Ntoumanis N. Relationships between exercise and three components of mental well-being in corporate employees. Psychol Sport Exerc, 2005, 6, 609-27.

29. Weinstein WS, Meyers AW. Running as a treatment of depression: is it worth it? Journal of Sport Psychology, 1983, $5,288-301$. 